\title{
Two Cases of Dyke-Davidoff Masson Syndrome
}

\section{İki Dyke-Davidoff Masson Sendromu Olgusu}

\author{
Sabiha TEZCAN, ${ }^{1}$ Çağrı ULUKAN, ${ }^{1}$ Seyda ERDOĞAN, ${ }^{1}$ Elif PEKER, ${ }^{2}$ Nursel AYDIN ${ }^{1}$ \\ 'Department of Neurology, Ankara University Faculty of Medicine, Ankara, Turkey \\ ${ }^{2}$ Department of Radiology, Ankara University Faculty of Medicine, Ankara, Turkey
}

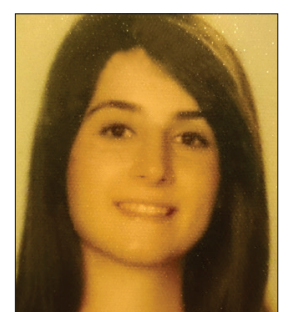

Nursel AYDIN, M.D.

\section{Summary}

Dyke-Davidoff Masson Syndrome (DDMS) is a rare syndrome characterized by seizures, facial asymmetry, and contralateral hemiplegia or hemiparesis. The typical radiological features of DDMS include cerebral hemiatrophy with ipsilateral hypertrophy of the skull and sinuses. It is usually diagnosed in childhood. Presently described are 2 rare cases of DDMS that were diagnosed in adults based on magnetic resonance imaging of the brain.

Keywords: Dyke-Davidoff Masson Syndrome; epilepsy; seizure.

\section{Özet}

Dyke-Davidoff Masson Sendromu (DDMS) nöbetler, fasiyal asimetri ve kontralateral hemiparezi ye da hemipleji ile karakterize nadir görülen bir sendromdur. Dyke-Davidoff Masson Sendromu ilk defa 1933 yılında, serebral hemiatrofi ile birlikte ipsilateral kemik ve sinüs hipertrofisi gibi karakteristik radyolojik bulgularla tanımlanmıştır. Dyke-Davidoff Masson Sendromu tanısının yetişkinlikte koyulması oldukça nadirdir. Biz burada manyetik rezonans görüntüleme ile yetişkinlikte tanısı koyulan iki DDMS olgusunu tanımladık.

Anahtar sözcükler: Dyke-Davidoff Masson sendromu; epilepsi; nöbet.

\section{Introduction}

Dyke-Davidoff Masson Syndrome (DDMS) is a rare cause of epileptic seizures. The syndrome is characterized by childhood onset seizures, facial asymmetry, and contralateral hemiplegia or hemiparesis. Here we present two cases of DDMS diagnosed in adulthood.

\section{Case Report}

Case 1-The patient was a 54-year-old man who presented at the hospital as a result of experiencing 3 generalized tonic seizures. His wife reported that the first had occurred 4 years earlier; while the patient was having breakfast, hesuddenly had tonic convulsions, fell down, and lost consciousness for about 2 minutes. He could not remember anything about this event. He indicated that he felt sleepy for an hour afterwards. Three years later, another seizure occurred, which was similar to the first. The third took place while he was sleeping, just before he came to the clinic.

The medical history of the patient included a head trauma when he was 11 months old and for which he was hospitalized for one month. The neurological examination performed at presentation revealed left homonymous hemianopia; the patient indicated that the condition had been present since childhood.

His blood count, renal and liver function tests, erythrocyte sedimentation rate, serum level of vitamin B12, and thyroid function tests were within normal limits. Electroencepha- 
logram was normal. Magnetic resonance image (MRI) of the brain revealed atrophy in right cerebral hemisphere, encephalomalacia, and increased volume of sinuses and the calvaria (Fig. 1). A diagnosis of DDMS was made. A hearing test performed by an otologist was normal.The patient scored 107 on an intelligence quotient test, so he was evaluated as of normal intelligence. The results of an ophtalmo- logical examination were compatible with corti- calblindness. He was treated with levetiracetam at a dose of 1000 $\mathrm{mg} /$ day and discharged from the hospital.

Case 2- A 38-year-old man presented with a 25-year history of generalized tonic clonic seizures. According to his wife, most of the seizures last approximately 10 to 15 minutes

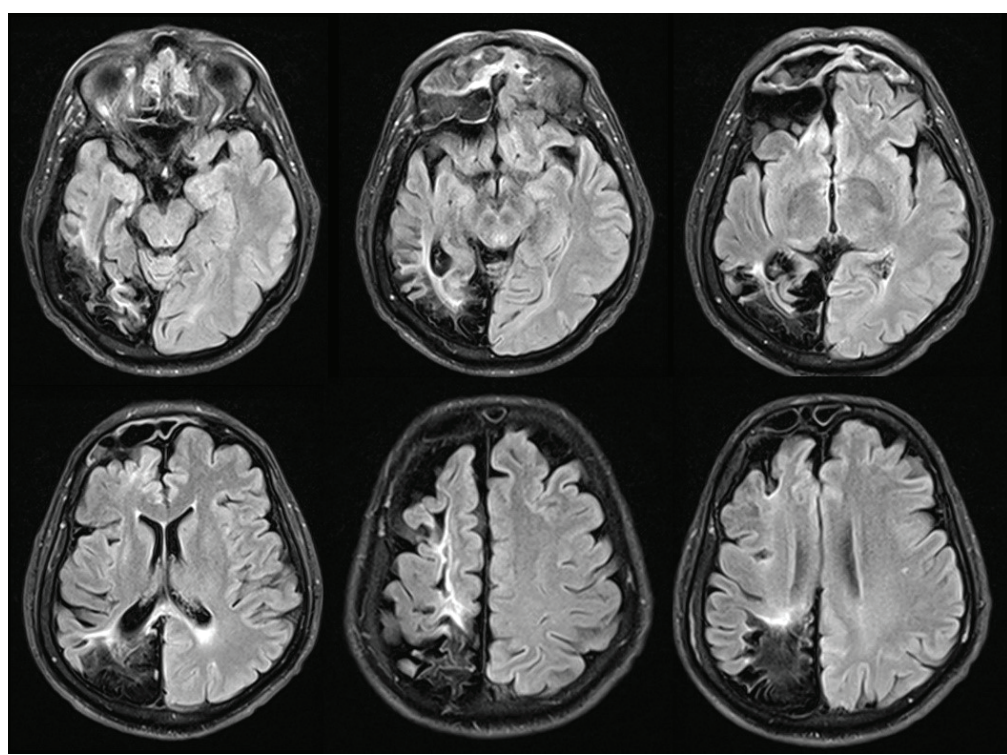

Fig. 1. Axial FLAIR image shows unilateral thickening of the skull vault bones, enlargement of the frontal sinus, unilateral atrophy of the right cerebral hemisphere and right parietooccipital encephalomalacia, gliotic areas in subcortical regions.

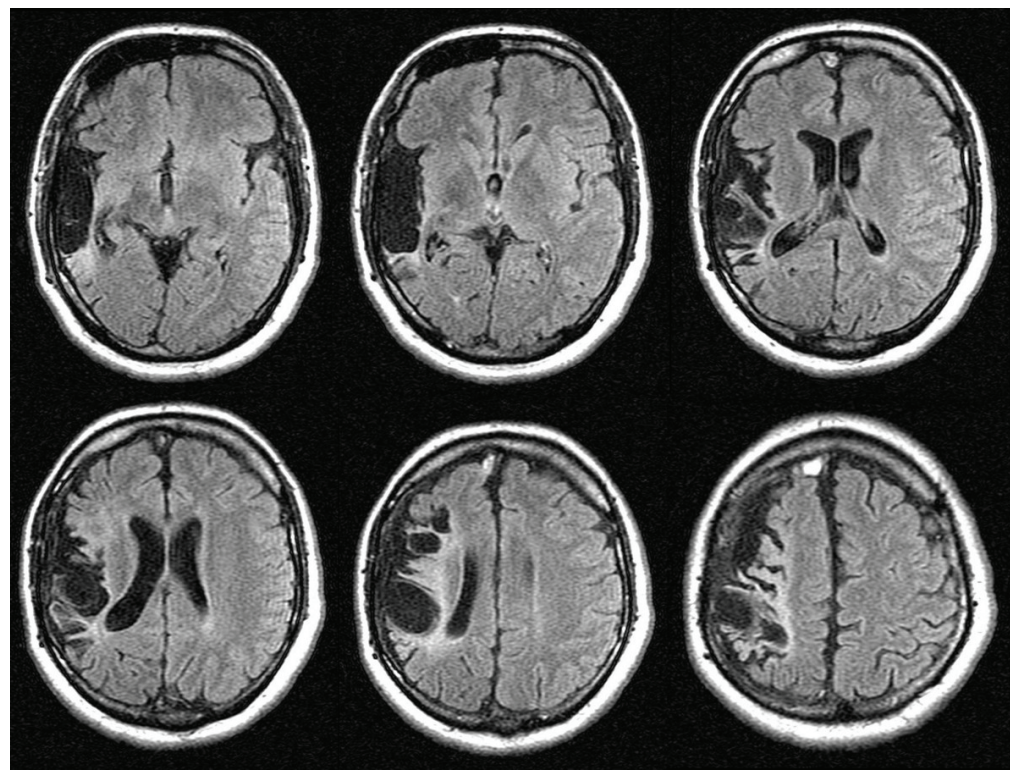

Fig. 2. Axial FLAIR image shows atrophy in right cerebral hemisphere, encephalomalasia and extraaxial lesions (dural calcifications) on both frontal area. 
with 30 minutes of postictal confusion. Hisseizureshadbecome more frequent, occurring 2 to 3 times a day for the year prior, mostly due to his irregular use of multiple antiepilectics and untreated urinary infections.

The medical history of the patient included meningitis and hospitalization for a month when he was 2 years old, as well as a head trauma when he was 8 after a bicycle accident. He could not learn to read or write.

His renal and liver function tests, serum level of vitamin B12, and thyroid function tests were within normal limits. He had leukocytosis with a high C-reactive protein level and erythrocyte sedimentation rate. Urinalysis revealed a urinary tract infection. Electroencephalogram results reported generalized sharp and spike wave activity on bilateral, diffuse $5-6 \mathrm{~Hz}$ theta waves. MRI of the brain revealed atrophy in right cerebral hemisphere, encephalomalacia, and extraaxiallesions(dural calcifications) on both frontal areas (Fig. 2). A diagnosis of DDMS was made. The patient was treated with the proper dose of antibiotics for his urinary tract infection and discharged from hospital with valproic acid treatment.

\section{Discussion}

DDMS was first described in 1933 with the characteristic radiological features of cerebral hemiatrophy with ipsilateral hypertrophy of the skull and sinuses. ${ }^{[1]}$ It is an uncommon condition, diagnosed based on clinical features and computed tomography (CT) or MRI findings. Diagnosis of DDMS is very rare in adulthood. ${ }^{[2-4]}$ It is thought to be secondary to cerebral injury in the fetal period or early childhood. ${ }^{[5]}$ The brain reaches three-fourths of its adult size by the end of the third year of life. When it fails to grow properly, theother structures tend to direct their growth inward; the calvarium thickens, and the paranasal sinuses and diploic space become enlarged. ${ }^{[5,6]}$ The typical clinical findings are seizures, hemiplegia or hemiparesis, and facial asymmetry. However, the clinical picture varies according to the extent of the brain injury. Mental retardation may or may not bepresent. ${ }^{[6]}$ Seizures may develop months or years after the onset of hemiparesis. ${ }^{[6]}$

DDMS may be associated with refractory seizures and the treatmentshouldfocusoncontroloftheseizureswithanticonvulsants. ${ }^{[7]}$ Multiple anticonvulsants maybe used. If the seizures are refractory, hemispherectomy may be considered. Prognosisis better if the onset of hemiparesisis after
2 years of age and in the absence of prolonged or recurrent seizures. ${ }^{[8]}$ Seizures may be focal or generalized. Complex partial seizures with secondary generalization have also been reported. ${ }^{[9]}$

Our first patient had a head trauma when he was 11 months old. Only left homonymous hemianopia was found on neurological examination; there was no indication of hemiplegia or hemiparesis, facial asymmetry, or mental retardation. Seizures appeared when he was 50 years old, although the left homonymous hemianopia had been present since childhood. He only had three seizures in four years. But his seizures could turning to refractory epilepsy. This case is interesting due to the age of diagnosis and mild clinical findings. The second patient was a more typical DDMS case with early onset refractory seizures, mental retardation, and electro-encephalogram findings.

The radiological differential diagnosis included large middle cerebral artery (MCA) infarction, Sturge-Weber syndrome, Rasmussen encephalitis, and hemimegalencephaly. ${ }^{[10]}$ MCA infarction is characterized by encephalomalacia in the vascular distribution of MCA and there is a lack of calvarial changes. Sturge-Weber syndrome is accompanied by cerebral atrophy associated with leptomeningeal angioma. ${ }^{[11]}$ Although calvarial findings may resemble DDMS, the presence of a facial port-wine stain, pial angioma, cortical calcification and ipsilateral enlargement of the choroid plexus are distinguishing features of this syndrome. ${ }^{[10]}$ Rasmussen encephalitis is a chronic, progressive inflammation of the brain, and a rare cause of intractable seizures ${ }^{[12]}$ Calvarial changes are absent, and unlike in DDMS, atrophy is centered in medial temporal lobe. ${ }^{[10-14]}$ Hemimegalencephaly is a congenital malformation with unilateral enlargement of the cerebrum. ${ }^{[14]}$ In contrast to DDMS, the smaller hemisphere is normal. ${ }^{[14]}$

In conclusion, despite mild clinical findings and late onset of seizures, DDMS should be considered in adults. Diagnosis is possible with brain $\mathrm{CT}$ or MRI findings in the event of clinical suspicion.

\section{Informed Consent}

Written informed consent was obtained from the patients who participated in this study.

\section{Peer-review}

Externally peer-reviewed. 


\section{Conflict of Interest}

None declared.

\section{Authorship Contributions}

Concept: S.T., Ç.U., S.E.; Design: S.T., Ç.Uu, S.E.; Supervision: S.E., N.A.; Materials: S.T., Ç.U., E.P.; Data collection \&/or processing: S.T., E.P.; Analysis and/or interpretation: S.T., S.E., E.P.; Literature search: S.T., E. P.; Writing: S.T., Ç.U., S.E, E.P.; Critical review: S.E., N.A.

\section{References}

1. Dyke CG, Davidoff LM, Masson CB. Cerebral hemiatrophy and homolateral hypertrophy of the skull and sinuses. Surg Gynecol Obstet 1933;57:588-600.

2. Shrestha B. Acquired cerebral hemiatrophy: Dyke-Davidoff-Masson Syndrome - a case report. Turk Neurosurg 2013;23(1):117-21.

3. Stoevesandt D, Stock K, Spielmann RP, Heine HJ, Paulsen F, Bräuer L. Postmortal diagnosis of a Dyke-Davidoff-Masson syndrome in a 75-year-old woman-a case report. Ann Anat 2009;191(2):225-7. [CrossRef]

4. Biçici V, Ekiz T, Bingöl I, Hatipoğlu C. Dyke-Davidoff-Masson syndrome in adulthood: A 50-year diagnostic delay. Neurology 2014;83(12):1121. [CrossRef]

5. Parker CE, Harris N, Mavalwala J. Dyke-Davidoff-Masson syndrome. Five case studies and deductions from dermatoglyph- ics. Clin Pediatr (Phila) 1972;11(5):288-92. [CrossRef]

6. Zilkha A. CT of cerebral hemiatrophy. AJR Am J Roentgenol 1980;135:259-62. [CrossRef]

7. Malik P, Garg R, Gulia AK, Kario J. Dyke-Davidoff-Masson Syndrome- a rare cause of refractory epilepsy. Iran J Psychiatry 2014;9(1):42-4. [CrossRef]

8. Pendse NA, Bapna P, Menghani V, Diwan A. Dyke-Davidoff-Masson syndrome (DDMS). Indian J Pediatr 2004;71(10):943.

9. Hsin YL, Chuang MF, Shen TW, Harnod T. Temporo-spatial analyses define epileptogenic and functional zones in a case of Dyke-Davidoff-Masson syndrome. Seizure 2011;20(9):713-6.

10. Osborn AG, Salzman KL, Barkovich AJ. Diagnostic Imaging: Brain. 2nd ed. Canada: Amirsys; 2010.

11. Lin DD, Barker PB, Kraut MA, Comi A. Early characteristics of Sturge-Weber syndrome shown by perfusion MR imaging and proton MR spectroscopic imaging. AJNR Am J Neuroradiol 2003;24(9):1912-5.

12. Geller E, Faerber EN, Legido A, Melvin JJ, Hunter JV, Wang Z, et al. Rasmussen encephalitis: complementary role of multitechnique neuroimaging. AJNR Am J Neuroradiol 1998;19(3):445-9.

13. Behera MR, Patnaik S, Mohanty AK. Dyke-Davidoff-Masson syndrome. J Neurosci Rural Pract 2012;3(3):411-3. [CrossRef]

14. Sato N, Yagishita A, Oba H, Miki Y, Nakata $Y$, Yamashita F, et al. Hemimegalencephaly: a study of abnormalities occurring outside the involved hemisphere. AJNR Am J Neuroradiol 2007;28(4):678-82. 